T. A. Romanko, I. V. Korzh, Ya. O. Proskurova

National University of Pharmacy, Ukraine

\title{
Clinical and economic analysis of PUblic Procurement OF ANTI-TUBERCULOSIS MEDICINES FOR TREATMENT OF PATIENTS WITH MULTI-RESISTANT TUBERCULOSIS
}

Aim. To make clinical and economic analysis of tender procurement of drugs for the treatment of patients with multiple resistance tuberculosisin Ukraine.

Materials and methods. The Ministry of Health of Ukraine for the years 2014-2018 on the volume of public purchases of anti-tuberculosis medicines has been used for the study. The total amount of public purchases of anti-tuberculosis medicines by all trade names, groupings of purchases by international non-proprietary nameshas been determined. During the study, the following methods of clinical and economic analysis used: ABC, XYZ, VEN-analyzes, integrated ABC/XYZ, ABC/VEN, $\mathrm{U}_{1} \mathrm{U}_{2} \mathrm{U}_{3} \mathrm{U}_{0} / A B C$-analyzes. Based on the results of integrated analyzes, matrix projections have been formed.

Results. According to the results of the ABC-public procurement analysis of tuberculosis medicines for 2014-2018, it was found that the total cost of purchasing medicines for the treatment of patients with multidrug-resistant tuberculosis had uneven dynamics. It is proved that during 2014-2018 the group $\mathrm{A}$ is dominated by anti-tuberculosis medicines of foreign production. The results of the matrix projection analysis of the integrated $A B C / X Y Z$ analysis show that, with significant financial costs for the procurement of anti-TB drugs, the frequency of purchases is unpredictable. Based on the results of the VEN analysis, it is proved that public procurement is carried out in compliance with the requirements of the relevant legal framework. The integrated ABC/VEN analysis demonstrates that during 2014-2015, the cost share for group A/E (meropon) was higher than for group A/V (levofloxacin, moxifloxacin, capreomycin), which does not fully meet the criteria of rational procurement. According to the results of the analysis of the matrix projection of the integrated $U_{1} U_{2} U_{3} U_{0} / A B C$ analysis, it is established that the group of not recommended medicines for the treatment of patients with multidrug-resistant tuberculosis includes three ATM (kanamycin, capreomycin, ofloxacin) with a cost amount of UAH 42520.3 thousand (part - $8.5 \%$ ).

Conclusions. Based on the results of a retrospective clinical and economic analysis of public procurement of anti-tuberculosis medicines for the period 2014-2018, it is possible to state the need for scientific substantiation for outpatient model providing medical and pharmaceutical assistance to patients with MRTB in accordance with their real needs in certain names of ATM health care capabilities and international standards.

Key words: clinical and economic analysis; public procurement; anti-tuberculosis medicines; multidrug-resistant tuberculosis

\section{Т. А. Романько, Ю. В. Корж, Я. О. Проскурова}

Національний фбарлацевтичний університет, Украйна

\section{КЛІНІКО-ЕКОНОМІЧНИЙ АНАЛІЗ ТЕНДЕРНИХ ЗАКУПІВЕЛЬ ЛІКАРСЬКИХ ЗАСОБІВ ДЛЯ ЛІКУВАННЯ ХВОРИХ НА МУЛЬТИРЕЗИСТЕНТНИЙ ТУБЕРКУЛЬОЗ}

Метою роботи було проведення клініко-економічного аналізу тендерних закупівель лікарських засобів для лікування хворих на мультирезистентний туберкульоз в Україні.

Матеріали та методи. Для проведення дослідження були використані офіційні дані МОЗ України за 2014-2018 рр. щодо обсягів публічних закупівель протитуберкульозних лікарських засобів. Визначена загальна сума публічних закупівель протитуберкульозних лікарських засобів за всіма торговими назвами та проведено групування сум закупівель за міжнародними непатентованими назвами. Під час проведення дослідження були використані такі методи клініко-економічного аналізу: АBC, XYZ, VEN-аналізи, інтегровані ABC/XYZ, ABC/VEN, $\mathrm{U}_{1} \mathrm{U}_{2} \mathrm{U}_{3} \mathrm{U}_{0} / \mathrm{ABC}$-аналізи. На підставі результатів інтегрованих аналізів сформовано матричні проєкції.

Результати. За результатами АВС-аналізу публічних закупівель протитуберкульозних лікарських засобів за 2014-2018 рр. встановлено, що загальна сума витрат на закупівлю лікарських засобів для лікування хворих на мультирезистентний туберкульоз мала нерівномірну 
динаміку. Доведено, що впродовж 2014-2018 рр. за групою А переважають протитуберкульозні лікарські засоби саме іноземного виробництва. Результати аналізу матричної проєкції інтегрованого ABC/XYZ-аналізу свідчать, що при значних фінансових витратах на закупівлю протитуберкульозних лікарських засобів частота закупівель $є$ непрогнозованою. На підставі отриманих результатів VEN-аналізу доведено, що публічні закупівлі виконуються з дотриманням вимог відповідної нормативно-правової бази. Інтегрований ABC/VEN-аналіз доводить, що впродовж 2014-2015 рр. частка витрат за групою А/Е (ПТЛЗ за МНН - меропонем) перевищувала витрати за групою A/V (левофлоксацин, моксифлоксацин, капреоміцин), що не повною мірою відповідає критеріям раціональних закупівель. За результатами аналізу матричної проєкції інтегрованого $\mathrm{U}_{1} \mathrm{U}_{2} \mathrm{U}_{3} \mathrm{U}_{0} / \mathrm{ABC}$-аналізу встановлено, що до групи не рекомендованих лікарських засобів для лікування хворих на мультирезистентний туберкульоз входять три препарати (канаміцин, капреоміцин, офлоксацин) із сумою витрат 42520,3 тис. грн (частка - 8,5\%).

Висновки. За результатами ретроспективного клініко-економічного аналізу публічних закупівель протитуберкульозних лікарських засобів у період 2014-2018 pр. можна говорити про необхідність наукового обгрунтування амбулаторної моделі надання медичної та фармацевтичної допомоги хворим на МРТБ відповідно до їхніх реальних потреб у тих чи інших протитуберкульозних лікарських засобах і з урахуванням фінансових можливостей галузі охорони здоров'я та міжнародних стандартів.

Ключові слова: клініко-економічний аналіз; публічні закупівлі; протитуберкульозні лікарські засоби; мультирезистентний туберкульоз

\section{Т. А. Романько, Ю. В. Корж, Я. А. Проскурова \\ Национальный фарлацевтический университет, Украина}

\section{КЛИНИКО-ЭКОНОМИЧЕСКИЙ АНАЛИЗ ТЕНДЕРНЫХ ЗАКУПОК ЛЕКАРСТВЕННЫХ СРЕДСТВ ДЛЯ ЛЕЧЕНИЯ БОЛЬНЫХ МУЛЬТИРЕЗИСТЕНТНЫМ ТУБЕРКУЛЕЗОМ}

Целью работы было проведение клинико-экономического анализа тендерных закупок лекарственных средств для лечения больных мультирезистентным туберкулезом в Украине.

Материалы и методы. Для проведения исследования были использованы официальные данные МЗ Украины за 2014-2018 гг. по объемам публичных закупок противотуберкулезных лекарственных средств. Определена общая сумма публичных закупок противотуберкулезных лекарственных средств по всем торговым наименованиям и осуществлена группировка сумм закупок по международным непатентованным наименованиям. При проведении исследования использованы следующие методы клинико-экономического анализа ABC, XYZ, VEN-анализы, интегрированные $\mathrm{ABC} / \mathrm{XYZ}, \mathrm{ABC} / \mathrm{VEN}, \mathrm{U}_{1} \mathrm{U}_{2} \mathrm{U}_{3} \mathrm{U}_{0} / \mathrm{ABC}$-анализы. На основании результатов интегрированных анализов сформированы матричные проекции.

Результаты. По результатам АВС-анализа публичных закупок противотуберкулезных лекарственных средств за 2014-2018 гг. установлено, что суммы расходов на закупку лекарств для лечения больных мультирезистентным туберкулезом имели неравномерную динамику. Доказано, что в течение 2014-2018 гг. по группе А преобладают противотуберкулезные лекарственные средства иностранного производства. Результаты анализа матричной проекции интегрированного ABC/XYZ-анализа свидетельствуют, что при значительных финансовых затратах на закупку противотуберкулезных лекарственных средств частота закупок является непрогнозируемой. На основании полученных результатов VEN-анализа доказано, что публичные закупки выполняются с соблюдением требований соответствующей нормативно-правовой базы. Интегрированный ABC/VEN-анализ показал, что в течение 2014-2015 гг. доля расходов по группе A/E (ПТЛС по МНН - меропонем) превышала расходы по группе A/V (левофлоксацин, моксифлоксацин, капреомицин), что не в полной мере соответствует критериям рациональных закупок. По результатам анализа матричной проекции интегрированного $\mathrm{U}_{1} \mathrm{U}_{2} \mathrm{U}_{3} \mathrm{U}_{0} / \mathrm{ABC}$ анализа установлено, что в группу не рекомендованных лекарственных средств для лечения больных мультирезистентным туберкулезом входят три препарата (канамицин, капреомицин, офлоксацин) с суммой расходов 42520,3 тыс. грн (доля - 8,5 \%).

Выводы. По результатам ретроспективного клинико-экономического анализа публичных закупок противотуберкулезных лекарственных средств за период 2014-2018 гг. можно судить о необходимости научного обоснования амбулаторной модели оказания медицинской и фармацевтической помощи больным мультирезистентным туберкулезом в соответствии с их реальными потребностями в тех или иных лекарственных средствах и с учетом финансовых возможностей здравоохранения и международных стандартов.

Ключевые слова: клинико-экономический анализ; публичные закупки; противотуберкулезные лекарственные средства; мультирезистентный туберкулез 


\section{STATEMENT OF THE PROBLEM}

The spread of socially dangerous diseases among the population is an over-threat to the national security of the country and is one of the main causes of disability, health, disability and mortality of the population. The problem of increasing the incidence, prevalence and mortality rates of socially dangerous diseases is a consequence of socio-economic processes in society, namely: poverty, social inequality and the need to constantly increase the amount of expenditures from the state budget. It should be noted that the fight against tuberculosis in Ukraine is recognized as one of the main priorities of public policy in the field of health and social development and is the subject of international obligations of Ukraine in the implementation of the provisions of the Association Agreement between Ukraine and the European Union [1]. Currently, Ukraine ranks second in Europe in terms of tuberculosis incidence and fourth in the world in its multidrug-resistant form [2]. At the same time, according to the International Classification of Diseases (ICD) - 10, there is no category of multidrug-resistant tuberculosis (MRTB). As part of the ICD-11, which is scheduled to be put into practice in 2021, MRTB disease has already been isolated [3].

In recent years, the issue of financial sustainability and effectiveness in health, particularly regarding the distinction between effectiveness and cost containment, has played an important role in strengthening health systems in the context of the WHO 2020 Health Policy in the WHO European Region [4]. In Ukraine, the issue of changing the system of financing the national health care system has become especially urgent recently. The government has adopted several decrees that outline strategic directions for building a health financing system. In particular, implementation of the state guaranteed package of medical and pharmaceutical assistance to the population; creation of a single national customer for medical services as a separate central executive body; creating new opportunities for local authorities to exercise their health care responsibilities; autonomy of medical and pharmaceutical care providers; introduction of effective payment methods for different types of medical care; development of a modern medical and pharmaceutical information management system [5]. At the same time, in the context of the transformation of the national health care system of particular socioeconomic relevance, the role of the rational role in the rational use of the funds necessary to fulfill state guarantees for the implementation of medical and pharmaceutical assistance to patients with socially-dangerous health diseases. According to the current legislative framework, tuberculosis patients are continuously and gratuitously provided with antituberculosis drugs (ATD) through public procure- ment during treatment [2]. Clinico-economical analysis (CEA) is one of the modern methods of conducting research into the indicators characterizing the volume and status of medical and pharmaceutical care [6].

\section{ANALYSIS OF RECENT RESEARCHES AND PUBLICATIONS}

In the works of domestic scientists, a great attention has been paid to the development of theoretical and applied approaches to the organization of rational pharmaceutical provision of patients based on the results of retrospective CEA [1, 6-12]. For the first time the methodology of carrying out CEA of tender purchases of drugs has been developed and tested by the researches of the department of organization and economics of pharmacy of NUPh in 2011 led by prof. A. S. Nemchenko [13]. It should be noted that in 2010 D. T. Sadova and O. L. Gromon the basis of CEA data, the optimization of the method for calculating the need for anti-tuberculosis drugs was optimized [14]. In 2018, I. O. Fedyak et al. performed a clinical and economic study of the features and problems of modern pharmaceutical emergency care in patients with tuberculosis and tuberculosis / HIV / AIDS in the in intensive care units in Ukraine [15].

\section{IDENTIFICATION OF ASPECTS OF THE PROBLEM UNSOLVED PREVIOUSLY}

At the same time, there are no scientific papers in Ukraine, which show the results of a retrospective CEA of public procurement of ATD used in long-term treatment regimens for patients with MRTB. The above facts substantiate the purpose and main directions of the study.

\section{OBJECTIVE STATEMENT OF THE ARTICLE}

The purpose of our study was to conduct a CEA tender for ATD for the treatment of patients with MRTB. To determine the current state of providing medical and pharmaceutical care for patients with MRTB and scientific substantiation of the directions of rational use of budget funds in conditions of scarcity of resources of the health care system, we developed an algorithm for conducting the study (Table 1).

Microsoft Office Excel 2017 spread sheet and standard variational statistics techniques were used in the statistical data processing, matrix projections of the results of integrated $\mathrm{ABC} / \mathrm{XYZ}$ analysis, $\mathrm{ABC} /$ VEN analysis and $U_{1} U_{2} U_{3} U_{0} / A B C$ analysis [16].

\section{PRESENTATION OF THE MAIN MATERIAL OF THE RESEARCH}

In the first stage, according to the data of public procurement volumes for the years 2014-2018, we conducted an $\mathrm{ABC}$ analysis (Table 2). It was found 


\section{GENERAL ALGORITHM OF THE STUDY}

\begin{tabular}{|c|c|}
\hline Stage description (features of calculations in studies) & Research results \\
\hline \multicolumn{2}{|c|}{ Stage I: Formation of a sample of ATD used in the treatment of MRTB, including long-term treatment regimens } \\
\hline $\begin{array}{l}\text { Formation of data bases for the years } 2014-2018 \text { on the volume of public purchases of } \\
\text { ATD. Determination of the total amount of public procurement of ATD by all trade } \\
\text { names of drug sover the period under investigation. Grouping of public procurement } \\
\text { amounts by international non-proprietary names (INN) }\end{array}$ & $\begin{array}{l}\text { Generation of data on the } \\
\text { total amount of public } \\
\text { procurement of ATD for } \\
2014-2018\end{array}$ \\
\hline \multicolumn{2}{|l|}{ Stage II: ABC-analysis } \\
\hline $\begin{array}{l}\text { Distribution of ATD by their level of spending into three groups: A - the most expend- } \\
\text { able ATD }(80.0 \%) \text {; C - average costs }(15.0 \%) \text {; C - low-cost ATD }(5.0 \%)\end{array}$ & $\begin{array}{l}\text { Definition INN ATD be- } \\
\text { longing to groups A, B and C }\end{array}$ \\
\hline \multicolumn{2}{|l|}{ Stage III: Integrated $\mathrm{ABC} / \mathrm{XYZ}$ analysis } \\
\hline $\begin{array}{l}\text { Distribution of ATD by coefficient of variation according to groups: } \mathrm{X}-\text { high frequency } \\
\text { of need }(0<10 \%) \text {; } \mathrm{Y} \text { is the average frequency of need }(10 \%<25 \%) \text {; } \mathrm{Z} \text { is the low fre- } \\
\text { quency of need }(25 \%<\infty) \text {. Combining ABC groups to XYZ to each INN: }(\mathrm{A} / \mathrm{X}, \mathrm{Y} . \mathrm{Z} \text {; } \\
\text { B / X, Y.Z; C / X, Y.Z) }\end{array}$ & $\begin{array}{l}\text { Construction of matrix } \\
\text { projection of results } \\
\text { ABC/XYZ-analysis }\end{array}$ \\
\hline \multicolumn{2}{|l|}{ Stage IV: conducting VEN analysis } \\
\hline $\begin{array}{l}\text { The distribution of ATD into categories V, E, N. The "V" was classified as ATD, which is } \\
\text { included in the National List of Major Medicines [9] and the Unified Clinical Protocol } \\
\text { [16]. Group "E" included ATD, which are listed only in the National List of Major Me- } \\
\text { dicinal Products or in treatment protocols. "N" - other ATD }\end{array}$ & $\begin{array}{l}\text { Definition of categories V, E, } \\
\mathrm{N} \text { of ATD for treatment of } \\
\text { MRTB according to public } \\
\text { procurement }\end{array}$ \\
\hline \multicolumn{2}{|l|}{ V stage: carrying out integrated $\mathrm{ABC} / \mathrm{VEN}$ analysis } \\
\hline $\begin{array}{l}\text { Combining } \mathrm{ABC} \text { groups and VEN categories into the appropriate INN to identify each } \\
\text { cost group in each category: }(\mathrm{A} / \mathrm{V}, \mathrm{A} / \mathrm{E}, \mathrm{A} / \mathrm{N}, \mathrm{B} / \mathrm{V}, \mathrm{B} / \mathrm{E}, \mathrm{C} / \mathrm{V}, \mathrm{C} / \mathrm{E})\end{array}$ & $\begin{array}{l}\text { Construction of matrix } \\
\text { projection of } \mathrm{ABC} / \mathrm{VEN} \\
\text { analysis results }\end{array}$ \\
\hline \multicolumn{2}{|c|}{ Stage VI: Development of theintegratedU1U2U3U0 / ABC analysis model for 2018} \\
\hline $\begin{array}{l}\text { Distribution of ATD according to utilization group U1, U2, U3, U0. Group U1 (priority) } \\
\text { includes ATD, which is part of the first group of WHO consolidated guidelines for the } \\
\text { treatment of patients with MRTB of ATD [21], U2 (additional) - ATD of the second } \\
\text { group of WHO guidelines, U3 (subsidiary) - ATD of the third group of WHO guide- } \\
\text { lines, U0 - ATD are not included in WHO guidelines. Combining U1U2U3U0 and ABC } \\
\text { groups into the appropriate INN for the purpose of establishing each cost-effectiveness } \\
\text { group: }\left(\mathrm{U}_{1} / \mathrm{A}, \mathrm{U}_{2} / \mathrm{A}, \mathrm{U}_{3} / \mathrm{A}, \mathrm{U}_{0} / \mathrm{A}, \mathrm{U}_{1} / \mathrm{B}, \mathrm{U}_{2} / \mathrm{B}, \mathrm{U}_{3} / \mathrm{B}, \mathrm{U}_{0} / \mathrm{B}, \mathrm{U}_{1} / \mathrm{C}, \mathrm{U}_{2} / \mathrm{C}, \mathrm{U}_{3} / \mathrm{C}, \mathrm{U}_{0} / \mathrm{C} \text { ) }\right.\end{array}$ & $\begin{array}{l}\text { Construction of matrix } \\
\text { projection of results } \\
\mathrm{U}_{1} \mathrm{U}_{2} \mathrm{U}_{3} \mathrm{U}_{0} / \mathrm{ABC}\end{array}$ \\
\hline
\end{tabular}

that the total cost of purchasing ATD for the treatment of patients with MRTB was uneven. Thus, the amount of purchases in 2015 compared to 2014 increased by UAH 221133.8 thousand, the growth rate amounted to $189.1 \%$. The dynamics of indicators for 2016-2015 indicates a decrease in procurement volumes by UAH 107714,7 thousand, and the growth rate was 77 \%. During 2016-2017, there was a tendency to reduce the cost of purchasing ATD by 46965.9 thousand UAH. (87 \% growth rate). In 2018, the volume of expenditures for the purchase of ATD showed a sharp increase by UAH 183740,87 thousand. (growth rate - $158 \%$ ) compared to 2017 data. In our opinion, the above trend may be due to many factors, such as an increase in the incidence of MRTB, the difficulty in selecting effective treatment regimens for chemotherapy, and inflationary processes.

AVS-method of analysis, it was determined that in 2014 the group A included four ATD INN for their share was $81.7 \%$ of total costs. In 2015 this group is represented by five ATD INN share was $80 \%$. In 2016 - seven INN at $76 \%$ of total purchases. In 2017-2018, it was purchased for budget funds for 5 ATD INN, which established $74 \%$ and $67 \%$ respectively. Analysis group showed that in 2014-2015. And 2017-2018 ATD number four was on the INN name, and the proportion of expenditure had some fluctuations. Thus, in 2014, the share of expenditures for the purchase of ATD was $16.9 \%$ of the total volume of expenditures for the purchase of ATD, in 2015 this group was $16.8 \%$, in 2017 the share of expenses corresponded to $18.6 \%$, and in 2018 it was $18 \%$. At the same time, the 2014 Group C was represented by 7 ATD INN accounting for $7 \%$ of the total expenditure for the purchase ATD. In 2015 Group C contained 5 ATD by INN proportion of $5.1 \%$. In 2016 it was purchased for the budget for the 6 ATD INN accounting for $9.5 \%$ of the overall structure, and in 2017 - 7 ATD INN or $6 \%$. In 2018 costs for the purchase of 8 ATD INN in relative terms was $6.7 \%$. It should be noted that this Group C was represented by the largest number ATD INN.

According to the results of the consolidated $\mathrm{ABC}$ analysis (Table 3), it was found that during 2014-2018 the number of trade names of ATD, 
THE RESULTS OF THE ABC-ANALYSIS IN PURCHASES ATD FOR TREATMENT MRTB

\begin{tabular}{|c|c|c|c|c|c|c|c|c|c|c|c|}
\hline \multicolumn{2}{|r|}{ ATD } & \multicolumn{2}{|l|}{2014} & \multicolumn{2}{|l|}{2015} & \multicolumn{2}{|l|}{2016} & \multicolumn{2}{|l|}{2017} & \multicolumn{2}{|l|}{2018} \\
\hline ATC & INN & Sum & $\begin{array}{l}\text { 亏े } \\
\text { ठ }\end{array}$ & Sum & 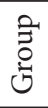 & Sum & 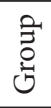 & Sum & $\begin{array}{l}\text { Oे } \\
\text { Oे }\end{array}$ & Sum & 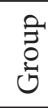 \\
\hline J01GB06 & Amikacin & 9498,019 & $\mathrm{~B}$ & 15052,618 & $\mathrm{~B}$ & 13943,240 & $\mathrm{~B}$ & 18481,381 & $\mathrm{~B}$ & 40102,602 & $\mathrm{~B}$ \\
\hline J04AK05 & Bedaquilin & - & - & - & - & - & - & - & - & 487,905 & $\mathrm{C}$ \\
\hline J04AD03 & Ethionamide & 1,854 & $\mathrm{C}$ & - & - & 2,323 & $\mathrm{C}$ & - & - & - & - \\
\hline J04AK02 & Ethambutol & 447,303 & $\mathrm{C}$ & 5040,752 & $\mathrm{C}$ & 14742,386 & $\mathrm{~B}$ & 9165,216 & $\mathrm{C}$ & 3804,142 & $\mathrm{C}$ \\
\hline J04AB30 & Capreomycin & 13062,835 & $\mathrm{~A}$ & 37480,885 & $\mathrm{~A}$ & 12784,055 & $\mathrm{~A}$ & 34319,357 & $\mathrm{~A}$ & 25186,396 & $\mathrm{~B}$ \\
\hline J01GB04 & Kanamycin & 5052,361 & $\mathrm{C}$ & 5554,655 & $\mathrm{C}$ & 4637,570 & $\mathrm{C}$ & 2677,250 & $\mathrm{C}$ & 7303,907 & $\mathrm{C}$ \\
\hline J04BA01 & Clofazimine & - & - & - & - & - & - & - & - & 64153,933 & $\mathrm{~A}$ \\
\hline J01MA12 & Levofloxacin & 44857,166 & $\mathrm{~A}$ & 64539,526 & $\mathrm{~A}$ & 58538,269 & $\mathrm{~A}$ & 69686,877 & $\mathrm{~A}$ & 97990,435 & $\mathrm{~A}$ \\
\hline J01XX08 & Linezolid & 7439,767 & $\mathrm{~B}$ & 30242,722 & $\mathrm{~B}$ & 20843,751 & $\mathrm{~A}$ & 26284,777 & $\mathrm{~A}$ & 43281,399 & $\mathrm{~A}$ \\
\hline J01MA14 & Moxy-phloxacin & 24006,257 & $\mathrm{~A}$ & 31030,277 & $\mathrm{~A}$ & 24194,323 & $\mathrm{~A}$ & 24105,456 & $\mathrm{~B}$ & 14282,099 & $\mathrm{~B}$ \\
\hline J01DH02 & Meropenem & 107676,503 & $\mathrm{~A}$ & 194277,43 & $\mathrm{~A}$ & 96027,018 & $\mathrm{~A}$ & 71374,357 & $\mathrm{~A}$ & 128436,147 & $\mathrm{~A}$ \\
\hline J04AA02 & Sodium & 12699,836 & $\mathrm{~B}$ & 23653,526 & $\mathrm{~B}$ & 27687,661 & $\mathrm{~A}$ & 15779,180 & $\mathrm{~B}$ & 5559,544 & $\mathrm{C}$ \\
\hline J04AK03 & Terizidone & - & - & - & - & 19105,424 & $\mathrm{~A}$ & 36,370 & $\mathrm{C}$ & 41526,728 & $\mathrm{~A}$ \\
\hline J01MA01 & Aminosalicylate & 5560,809 & $\mathrm{C}$ & 4267,061 & $\mathrm{C}$ & 4716,286 & $\mathrm{C}$ & 4547,148 & $\mathrm{C}$ & 10030,018 & $\mathrm{~B}$ \\
\hline J04AD01 & Ofloxacin & 4115,251 & $\mathrm{C}$ & 10694,062 & $\mathrm{~B}$ & 12045,528 & $\mathrm{C}$ & 3196,829 & $\mathrm{C}$ & 8924,169 & $\mathrm{C}$ \\
\hline J04AK01 & Protonamide & 1343,066 & $\mathrm{C}$ & 9102,617 & $\mathrm{C}$ & 17847,134 & $\mathrm{~B}$ & 1098,226 & $\mathrm{C}$ & 1045,284 & $\mathrm{C}$ \\
\hline J01GA01 & Pyrazinamide & 81,147 & $\mathrm{C}$ & 18,763 & $\mathrm{C}$ & 38,191 & $\mathrm{C}$ & 74,884 & $\mathrm{C}$ & 47,119 & $\mathrm{C}$ \\
\hline J04AB01 & Streptoms- & 12264,397 & $\mathrm{~B}$ & 38285,402 & $\mathrm{~A}$ & 34372,476 & $\mathrm{~A}$ & 33732,421 & $\mathrm{~A}$ & 6138,764 & $\mathrm{C}$ \\
\hline \multicolumn{2}{|l|}{ Total } & \multicolumn{2}{|c|}{248106,570} & \multicolumn{2}{|c|}{469240,296} & \multicolumn{2}{|c|}{361525,634} & \multicolumn{2}{|c|}{314559,729} & \multicolumn{2}{|c|}{498300,591} \\
\hline
\end{tabular}

taking into account the forms of issue, had uneven dynamics. Thus, in 2014, their number was 220 items, the share in group A was $53.2 \%$ of the total number of trade names of ATD, group B - $20 \%$, group C $26.8 \%$. In 2015, when the cost was doubled compared to 2014, the number of ATD by trade names amounted to 170 with shares A (61.8\%), B (20\%), $\mathrm{C}(18.2 \%)$. In 2016, 185 trade names of ATD were purchased, the share in Group A was $73.5 \%, \mathrm{~B}-$ $10.3 \%, C-16.2 \%$. The valuesobtained for 2017 showed the presence of 159 trade names with shares in Group A (68.5 \%), B (12.6\%), C (18.9\%). In 2018 , the number of trade names amounted to 171 ATD names, which, when divided into groups, was A (63.7\%), B (24\%), C (12.3\%).
It is established that during 2014-2018 Group A is dominated by foreign production ATD. Thus, their share in 2014 was $66.7 \%$, and in $2018-56.8 \%$. Considering the unstable economic situation in the country, the significant dominance of foreign production drugs in the procurement of ATD has extremely negative consequences for society. However, it should be noted that in 2018 there is a positive tendency for a slight increase in the share of domestic production ATD. It was found that during 2014-2018, the share of expenditures for the purchase of domestic production of ATD increased by $10 \%$. It should be noted that in groups B and $\mathrm{C}$ there was a slight tendency of prevalence of domestic production ATD.

Table 3

\section{RESULTS OF SUMMARY ABC - ANALYSIS OF PROCUREMENT VOLUME OF ATM FOR TREATMENT OF PATIENTS WITH MRTB}

\begin{tabular}{|c|c|c|c|c|c|c|c|c|c|c|c|c|c|c|c|c|c|c|c|c|}
\hline \multirow[b]{2}{*}{ Group } & \multicolumn{4}{|c|}{2014} & \multicolumn{4}{|c|}{2015} & \multicolumn{4}{|c|}{2016} & \multicolumn{4}{|c|}{2017} & \multicolumn{4}{|c|}{2018} \\
\hline & Z & 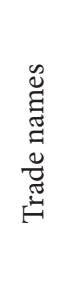 & 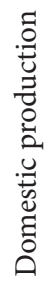 & 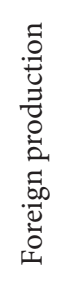 & 吕 & 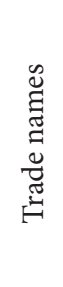 & 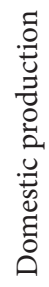 & 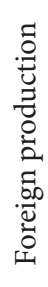 & Z & 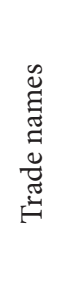 & 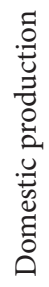 & 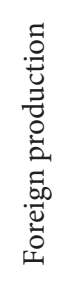 & Z & 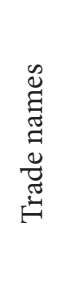 & 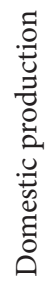 & 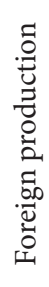 & Z & 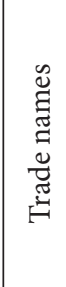 & 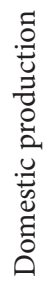 & 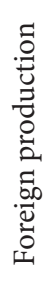 \\
\hline $\mathrm{A}$ & 4 & 117 & 39 & 78 & 5 & 105 & 39 & 66 & 7 & 136 & 50 & 86 & 5 & 109 & 40 & 69 & 5 & 109 & 47 & 62 \\
\hline$B$ & 4 & 44 & 21 & 23 & 4 & 34 & 22 & 12 & 3 & 19 & 13 & 6 & 3 & 20 & 12 & 8 & 4 & 41 & 27 & 14 \\
\hline $\mathrm{C}$ & 7 & 59 & 32 & 27 & 5 & 31 & 24 & 7 & 6 & 30 & 22 & 8 & 7 & 30 & 23 & 7 & 8 & 21 & 15 & 6 \\
\hline Total & 15 & 220 & 92 & 128 & 14 & 170 & 85 & 85 & 16 & 185 & 85 & 100 & 15 & 159 & 75 & 84 & 17 & 171 & 89 & 82 \\
\hline
\end{tabular}




\section{MATRIX PROJECTION RESULTS INTEGRATED ABC/XYZ-ANALYSIS OF PUBLIC PROCUREMENT ATD FOR 2014-2018}

\begin{tabular}{|l|c|c|c|c|c|c|c|c|c|}
\hline \multirow{2}{*}{ Indicators } & \multicolumn{9}{c|}{ Categories } \\
\cline { 2 - 10 } & $\mathrm{A} / \mathrm{X}$ & $\mathrm{A} / \mathrm{Y}$ & $\mathrm{A} / \mathrm{Z}$ & $\mathrm{B} / \mathrm{X}$ & $\mathrm{B} / \mathrm{Y}$ & $\mathrm{B} / \mathrm{Z}$ & $\mathrm{C} / \mathrm{X}$ & $\mathrm{C} / \mathrm{Y}$ & $\mathrm{C} / \mathrm{Z}$ \\
\hline INN & - & 1 & 5 & - & - & 4 & - & - & 7 \\
\hline Costs, thousands UAH & - & 19603,1 & 218187,2 & - & - & 47597,9 & - & - & 29900,7 \\
\hline
\end{tabular}

In the process of investigating the volume of purchases of ATD, there is a need to determine the validity of the purchase of certain ATD. ABC/XYZ makes it possible to rank procurement costs by taking into account the variation coefficient (VC) of purchases of individual drugs. As the list of drugs under which purchases are made is formed on the urgent need of health care institutions, we conducted the ABC/XYZ-analysis for 2014-2018, for the results of which the matrix projection was formed (Table 4).

According to the results of the integrated $\mathrm{ABC} / \mathrm{XYZ}$ analysis, it was proved that no drugs were included in the $\mathrm{ABC}$ groups by the $\mathrm{ABC}$ groups. The same trend was observed for category Y (average Purchase Quotas) and groups B and C. At the same time, it was found that during 2014-2028, category A/Y (the highest costs with average Purchase Quotas) was represented by such ATD INN, as moxifloxacin, the variable share of which accounted for $25 \%$ of total procurement costs. The A/Z category (high cost with average Purchase Quotas) included five ATD INN, namely: meropenem - the variable proportion of purchases of ATD was $39 \%$, levofloxacin - $29 \%$, linezolid - $51 \%$, cycloserine $59 \%$, capreomycin - $47 \%$. Category B/Z (Medium Costs with Low Purchase Costs) is represented by four ATD INN: amikacin - $62 \%$, sodium aminosalicylate - $51 \%$, clofazimine $-224 \%$, protionamide $-51 \%$. Category C/Z (lower costs low in April purchases) includes seven PTLZ by INN, namely ethambutol - $83 \%$, pyrazinamide $-122 \%$ ofloxacin - $41 \%$, kanamycin - $33 \%$, bedakvilin - $224 \%$, streptomycin - $50 \%$, ethionamide $-138 \%$.

The results of the integrated $\mathrm{ABC} / \mathrm{XYZ}$ analysis showed that for the period 2014-2018, $90 \%$ of expenditures are in the $\mathrm{Z}$ category across all $\mathrm{ABC}$ groups. The above fact shows that a significant amount of expenditure on the purchase ATD was distributed unpredictably. It should be noted that the application of such procurement criteria makes it impossible to plan and budget for the future.

According to the results of the VEN analysis, it was established that during 2014-2018, a greater number of ATD for the treatment of patients with MRTB were included in the category " $V$ ". Thus, in 2014 , the share of ATD with the index " $V$ " was $93.3 \%$, in $2015-92.9 \%$, in $2016-93.7 \%$, in $2017-93.3 \%$, and in $2018-88.2 \%$. It should be noted that none of the ATD purchased for the budget were assigned to the $\mathrm{N}$ category. The above fact should be assessed as a positive trend, both medically and economically, indicating compliance with the requirements of the relevant legal framework in the course of public procurement.

In the next phase of the study we conducted an integrated ABC/VEN analysis and built a matrix projection (Table 5).

Based on the integrated ABC/VEN analysis, we can state the following. In 2014-2015, the state's financial resources were primarily directed to the

Table 5

\section{MATRIX PROJECTION OF THE INTEGRATED ABC/VEN ANALYSIS OF PUBLIC PROCUREMENT OF ATD FOR 2014-2018}

\begin{tabular}{|c|c|c|c|c|c|c|c|c|c|c|c|c|c|c|c|}
\hline \multirow[b]{2}{*}{ Group } & \multicolumn{3}{|c|}{2014} & \multicolumn{3}{|c|}{2015} & \multicolumn{3}{|c|}{2016} & \multicolumn{3}{|c|}{2017} & \multicolumn{3}{|c|}{2018} \\
\hline & Z & 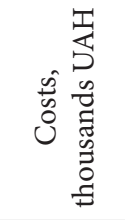 & 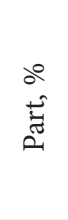 & Z & 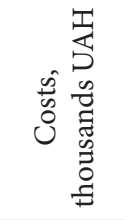 & 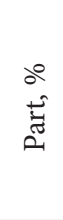 & Z & 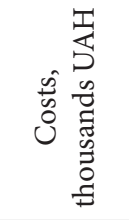 & 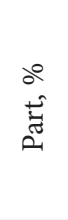 & 吕 & 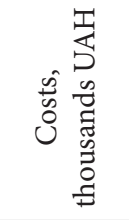 & 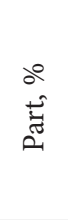 & 吕 & 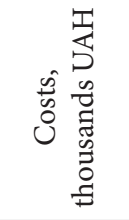 & $\frac{d^{\circ}}{\underbrace{*}}$ \\
\hline $\mathrm{A} / \mathrm{V}$ & 3 & 81926,3 & 33 & 4 & 171336,1 & 36,5 & 6 & 184742 & 51,1 & 4 & 164023,3 & 52,1 & 4 & 246952,3 & 49,6 \\
\hline $\mathrm{A} / \mathrm{E}$ & 1 & 107676,5 & 43,4 & 1 & 194277,4 & 41,4 & 1 & 96027 & 26,6 & 1 & 71374,4 & 22,7 & 1 & 128436,2 & 25,7 \\
\hline $\mathrm{B} / \mathrm{V}$ & 4 & 41902,0 & 16,9 & 4 & 79642,9 & 17,0 & 3 & 46532,7 & 12,9 & 3 & 58366,0 & 18,5 & 4 & 89601,2 & 18 \\
\hline $\mathrm{B} / \mathrm{E}$ & - & - & - & - & - & - & - & - & - & - & - & - & - & - & - \\
\hline $\mathrm{C} / \mathrm{V}$ & 7 & 16601,7 & 6,7 & 5 & 23983,8 & 5,1 & 6 & 34223,9 & 9,4 & 7 & 20796,0 & 6,7 & 8 & 33310,8 & 6,7 \\
\hline $\mathrm{C} / \mathrm{E}$ & - & - & - & - & - & - & - & - & - & - & - & - & - & - & - \\
\hline Total & 15 & 248106,5 & 100 & 14 & 469240,2 & 100 & 16 & 361525,6 & 100 & 15 & 314559,7 & 100 & 17 & 498300,5 & 100 \\
\hline
\end{tabular}


MATRIX PROJECTION INTEGRATED $\mathrm{U}_{1} \mathrm{U}_{2} \mathrm{U}_{3} \mathrm{U}_{0} / A B C$ ANALYSIS FOR PUBLIC PROCUREMENT ATD 2018

\begin{tabular}{|c|c|c|c|c|c|c|c|}
\hline \multirow[b]{2}{*}{ Utility groups } & \multicolumn{2}{|l|}{ A } & \multicolumn{2}{|l|}{$\mathrm{B}$} & \multicolumn{2}{|l|}{$\mathrm{C}$} & \multirow[b]{2}{*}{ Total } \\
\hline & INN & $\begin{array}{c}\text { Costs, } \\
\text { thousand } \\
\text { UAH }\end{array}$ & INN & $\begin{array}{c}\text { Costs, } \\
\text { thousand } \\
\text { UAH }\end{array}$ & INN & $\begin{array}{c}\text { Costs, } \\
\text { thousand } \\
\text { UAH }\end{array}$ & \\
\hline $\mathrm{U}_{1}$ priority & $\begin{array}{l}\text { Levofloxacin } \\
\text { Linezolid } \\
\end{array}$ & 141271,7 & Moxifloxacin & 14282,2 & Bedaquilin & 487,9 & 156041,8 \\
\hline $\mathrm{U}_{2}$ extra & $\begin{array}{l}\text { Clofazimine } \\
\text { Terisidone }\end{array}$ & 105680,7 & - & - & Cycloserin & 6138,8 & 111819,5 \\
\hline $\mathrm{U}_{3}$ auxiliary & Meropenem & 128436,2 & Amikacin & 40102,6 & \begin{tabular}{|c} 
Ethambutol \\
Pyrazinamide \\
Streptomycin \\
Ethionamide \\
Protonamide \\
Sodium \\
aminosalicylate
\end{tabular} & 19380,1 & 187918,9 \\
\hline $\begin{array}{l}\mathrm{U}_{0} \\
\text { Not recommended }\end{array}$ & - & - & $\begin{array}{c}\text { Capreomycin } \\
\text { Ofloxacin }\end{array}$ & 35216,4 & Kanamicin & 7303,9 & 42520,3 \\
\hline Total & \multicolumn{2}{|c|}{375388,6} & \multicolumn{2}{|c|}{89601,1} & \multicolumn{2}{|c|}{33310,8} & 498300,5 \\
\hline
\end{tabular}

acquisition of A/E rated ATD. Thus, the share of A/E group expenditures in the total purchased ATD ranged from $43.40 \%$ (2014) to $41.4 \%$ (2015), and drugs with $\mathrm{A} / \mathrm{V}$ status in the smaller range of values from $33 \%$ (2014) to $36.5 \%$ (2015). At the same time, significant changes took place during 2016-2018. Yes, the share of A/E expenses was $26.6 \%$ (2016), $22.7 \%$ (2017) to $25.7 \%$ (2018). Whereas A/V group ATD accounted for $51.5 \%$ (2016), $52.1 \%$ (2017) and $49.6 \%$ (2018). It has been established that there are no $\mathrm{B} / \mathrm{E}, \mathrm{C} / \mathrm{E}$ medicines in the public procurement of ATD. It was found that from 2014 to 2015, the share of expenditures for group A/E (ATD INN - meroponium) exceeded for group A/V (levofloxacin, moxifloxacin, capreomycin), which did not fully meet the criteria of rational procurement. However, there has been a positive trend since 2016 in reducing the cost share per group $(\mathrm{A} / \mathrm{E})$.

In Ukraine, as of 2020, the standard treatment for MRTB is the Unified Tuberculosis Clinical Protocol (MOH Order No. 620 of 04.09.2014) [17]. However, it should be noted that in accordance with the order of the Ministry of Health of Ukraine dated December 29, 2016 No. 1422 "On Amendments to the Order of the Ministry of Health of Ukraine dated September 28, 2012 No. 751" Ukrainian doctors have the right to base their recommendations on modern patients. international protocols [18-21].

In order to determine the distribution of public spending for medical and pharmaceutical care to MRTB with international standards we had spent integrated $\mathrm{U}_{1} \mathrm{U}_{2} \mathrm{U}_{3} \mathrm{U}_{0} / \mathrm{ABC}$ analysis of public procurement PTLZ for 2018 For this we have allocated ATD groups utilitarian $\left(\mathrm{U}_{1}, \mathrm{U}_{2}, \mathrm{U}_{3}, \mathrm{U}_{0}\right)$. Thus, according to the consolidated guidelines WHO treatment MRTB ATD based on recent data regarding the relationship between efficacy and safety are divided into three groups:

- the first group (priority $\left(\mathrm{U}_{1}\right)$ ) the inclusion of three ATD INN: levofloxacin / moxifloxacin, bedakvalin, linezolid;

- $\quad$ the second group (additional $\left(\mathrm{U}_{2}\right)$ ): - ATD to be included in the following treatment regimens - clafazimine, cycloserine / terisidone;

- the third group (Auxiliary $\left(\mathrm{U}_{3}\right)$ ) - ATD used to complete the course of treatment and if priority and additional ATD cannot be used: ethambutol, delamidine, pyrazinamide, imipenem-cilastatin or meropenem, amikacin (or streptomycin), ethionamide or prothionamide, paraaminosalicylic acid.

- the fourth group $\left(\mathrm{U}_{0}\right)$ - not recommended for use in the treatment of patients with MRTB.

Based on the results of a public procurement analysis of ATD for 2018, it was found that the ranking of ATD by utilitarian index (Table 6) showed significant differences in the structure of cost sharing. Thus, in 2018, the $\mathrm{U}_{1}$ group included four ATD INN with a total procurement cost of UAH 156041.8 thousand and the share was $31.3 \%$ of the total cost. The $\mathrm{U}_{2}$ group includes three ATD, the cost of which was 111819.5 thousand UAH with a share $-22.4 \%$. The $\mathrm{U}_{3}$ group includes eight ATD for the total amount of procurement 187918.9 thousand UAH with a share of $37.8 \%$. It should be noted that the $\mathrm{U}_{0}$ group (not recommended) included three ATD (kanamycin, capreomycin, ofloxacin) with a cost of 42520.3 thousand UAH (part - $8.5 \%$ ).

It has been proven that in 2018, the cost structure for the procurement of ATD does not meet the treatment priorities proposed by WHO. It was established that the group $\mathrm{U}_{1} / \mathrm{A}$ includes two ATD 
(levofloxacin and linezolid). At the same time, groups $\mathrm{U}_{1} / \mathrm{B}$ and $\mathrm{U}_{1} / \mathrm{C}$ contained only one ATD MNN. It should be noted that innovative ATD Bedaquilin, which has been recommended since 2013 by WHO for the treatment of MRTB, is registered in Ukraine only in 2018. This fact explains the small part of its costs in purchasing in 2018. Particular attention is drawn to the fact that the $\mathrm{U}_{0} / \mathrm{B}$ group was formed by two ATD INN for the total procurement amount of UAH 35216,4 thousand.

Structural analysis of the matrix projection of integrated $\mathrm{U}_{1} \mathrm{U}_{2} \mathrm{U}_{3} \mathrm{U}_{0} / \mathrm{ABC}$ analysis by ATD groups showed the necessity of introducing scientifically sound approaches to determine the feasibility of their acquisition and the calculation of procurement costs. Yes, meropenem is a member of the $\mathrm{U}_{3} / \mathrm{A}$ group. That is, this ATD is ancillary in some cases of resistance, which allows us to assume its small need in the treatment of patients with MRTB. At the same time, it has been proven that the highest expenditures in 2018 are related to the procurement of MTTB meropenem (25\% of total expenditures) by the budget for the ATD. It should also be noted that meroponium is a parenteral drug that is currently recommended in extreme cases. Thus, an outpatient model of treatment for patients with MRTB is currently being implemented in Ukraine, based on the refusal to use injectable ATD. The results of the study indicate that there is an urgent need to revise treatment approaches in the light of international standards, which will certainly have an impact on the composition and structure of public procurement of ATD. The above determines the directions of further socio-economic research.

\section{CONCLUSIONS AND PROSPECTS FOR FURTHER RESEARCH}

1. The ABC conducted analysis of public procurement of PATD for 2014-2018 shows that the total cost of purchasing ATD for the treatment of patients with MRTB was uneven. It is established that during 2014-2018 Group A is dominated ATD by foreign production. Thus, their share in 2014 was $66.7 \%$, and in $2018-56.8 \%$. It is proved that during 2014-2018 the share of costs for the purchase of domestic ATD increased by $10 \%$. In groups $\mathrm{B}$ and $\mathrm{C}$ there was a slight tendency of prevalence of domestic production ATD.

2. The results of the structural analysis of the matrix projection of the integrated $\mathrm{ABC} / \mathrm{XYZ}$ analysis prove that for the years 2014-2018, a considerable part of the expenditures fall into the category A/Z. The aforementioned fact indicates that there is a significant financial cost for the procurement of ATD whose frequency of purchases is not consistently predicted.

3. The VEN analysis of the public procurement of ATD revealed that during 2014-2018, a larger number of ATD for the treatment of patients with MRTB were included in the $\mathrm{V}$ group, they were vital and purchased in accordance with the Unified Clinical Protocol. Thus, in 2014, the share of ATD with the index "V" was $93.3 \%$, in $2015-92.9 \%$, in $2016-93.7 \%$, in 2017 $93.3 \%$, and in $2018-88.2 \%$. The absence of ATD in group $\mathrm{N}$ has been proved, which indicates compliance with the requirements of the relevant legal framework in the course of public procurement.

4. The integrated ABC/VEN analysis made it possible to establish that during 2014-2018 there were no drugs with the status of $\mathrm{B} / \mathrm{E}, \mathrm{C} / \mathrm{E}$ in the procurement of ATD. It was proved that during the period 2014-2015, the share of expenditures for group A/E (ATD according to INN - meroponium) exceeded for group A/V (levofloxacin, moxifloxacin, capreomycin), which does not fully meet the criteria of rational procurement. In 2016, there is a positive trend of decreasing the share of expenses by group $(\mathrm{A} / \mathrm{E})$.

5. The results of the matrix projection analysis of integrated $\mathrm{U}_{1} \mathrm{U}_{2} \mathrm{U}_{3} \mathrm{U}_{0} / \mathrm{ABC}$ analysis of ATD groups have shown the need to implement scientifically sound approaches to determine the feasibility of their acquisition, taking into account international standards and the calculation of procurement costs. It was established that the $\mathrm{U}_{0}$ group (not recommended for use in the treatment of patients with MRTB) included three ATD (kanamycin, capreomycin, ofloxacin) with a cost of 42520.3 thousand UAH (part $8.5 \%$ ). Thus, the $\mathrm{U}_{0} / \mathrm{B}$ group was formed by two ATD INN for the total procurement amount of 35216,4 thousand UAH.

6. The retrospective CEA of public procurement of ATD used in long-term treatment regimens for MRTB patients makes it possible to state the need for a scientific substantiation of the outpatient model of medical and pharmaceutical care for patients with MRTB in accordance with their actual needs in those or other financial needs health care and international standards.

Conflict of interests: authors have no conflict of interests to declare.

ABREVIATIONS: ICD, International Classification of Diseases; MRTB, multidrug-resistant tuberculosis; ATD, anti-tuberculosis drugs; CEA, clinico-economical analysis.

\section{REFERENCES}

1. Про ратифікацію Угоди про позику (Проект «Контроль за туберкульозом та ВІЛ/СНІДом в Україні») між Україною та Міжнародним банком реконструкції та розвитку: Закон України № 1287 від 18.11.2003 р. [Електронний ресурс]. - Режим доступу : https://zakon.rada.gov.ua/laws/show/1287-15 
2. Про протидію захворюванню на туберкульоз : Закон України № 2586 від 28.12.2015 р. [Електронний pecypc]. - Режим доступу : https://zakon.rada.gov.ua/laws/show/2586-14

3. WHO releases new International Classification of Diseases (ICD 11) // World Health Organization (en-US).

4. Health systems expanding in the context of Health 2020: challenges and priorities in the WHO European Region // Division of Health Systems and Public Health, (Expertmeeting Barcelona, Spain, 3-4 November 2014). World Health Organization, 2015. - P. 3-4.

5. Про схвалення Концепції реформи фінансування системи охорони здоров'я : розпорядження Кабінету Міністрів України від 30.11.2016 р. № 1013-р [Електронний документ]. - Режим доступу : http://zakon3.rada.gov.ua/laws/show/1013-2016-\%D1\%80.

6. Кабачна, А. В. Індекс утилітарності як індикатор оцінки доцільності внесення лікарських засобів до локального формуляра / А. В. Кабачна, Е. В. Шелкова, О. Г. Кабачний // Менеджмент та маркетинг у складі сучасної економіки, науки і освіти, практики: матеріали III наук.-практ. Інтернет-конф. (26- 27 берез. 2015 р.). - Х., 2015.- С. 118-120.

7. Клініко-економічні аспекти фармакотерапії хворих на виразкову хворобу шлунка / Л. В. Яковлєва, О. О. Герасимова, А. С. Горбачова, А. А. Красюк // Фармац. часопис. - 2015. - № 3. - С. 83-87. https:// doi.org/10.11603/2312-0967.2015.3.4939

8. Котвіцька, А. А. Науково-практичні підходи до створення локального формуляру лікарських засобів у лікувально-профілактичних закладах стаціонарного типу / А. А. Котвіцька, О. І. Красуля, I. В. Кубарєва // Управління, економіка та забезпечення якості в фармації. - 2012. - № 6. - С. 70-75.

9. Котвіцька, А. А. Оцінка фармакотерапії хворих на кір в умовах стаціонару методами АВC-, VENта частотного аналізу / А. А. Котвіцька, О. В. Кононенко // Фармац. журн. - 2015. - № 6. - С. 3-9.

10. Мнушко, 3. М. Фармакоеокномічні підходи до створення оптимального переліку лікарських препаратів, необхідних для закупівлі за бюджетні кошти (на прикладі гематологічного відділення клінічної лікарні): метод. рек. / З. М. Мнушко, Н. В. Шолойко. - Х.: Вид-во НФаУ, 2008. - 19 с.

11. Панфілова, Г. Л. Результати дослідження тендерних закупівель лікарських засобів для онкогематологічних хворих в Україні / Г. Л. Панфілова, О. В. Цурікова // Запорізький мед. журн. - 2014. - № 1 (82) - С. 98-103.

12. Результати клініко-економічного аналізу споживання лікарських препаратів хворими на гострий лімфоїдний та мієлоїдний лейкоз в Україні / Г. Л. Панфілова, О. В. Цурікова, О. В. Доровський, Ю. В. Корж // Клінічна фармація. - 2015. - № 4. - C. 17-23. http://dx.doi.org/10.24959/cphj.15.1361

13. The study of the state of pharmaceutical provision for patients with cardiovascular diseases using ABCand VEN-analyses / A. S. Nemchenko, V. N. Nazarkina, Yu. Ye. Kurylenko // Вісник фармаціï. - 2018. - № 3 (95). - C. 44-48. https://doi.org/10.24959/nphj.18.2218

14. Немченко, А. С., Методика проведення клініко-економічного аналізу тендерних закупівель ЛЗ за державними цільовими програмами: метод. рек. / А. С. Немченко, К. Л. Косяченко, Г. Л. Панфілова. - Х. : НФаУ, 2011. - 26 c.

15. Садова, Д. Т. Оптимізація методики розрахунку потреби в протитуберкульозних препаратах на основі аналізу карт історій хвороби / Д. Т. Садова, О. Л. Гром // Фармац. журн. - 2010. - № 4. - С. 27-31.

16. Федяк, I. О. Клініко-економічна оцінка фармакотерапії хворих на туберкульоз у відділеннях інтенсивної терапії протитуберкульозних диспансерів / І. О. Федяк, І. Г. Купновицька, Н. Р. Гриник // Соціальна фармація в охороні здоров’я. - 2018. - Т. 4, № 2. - С. 19-28. http://dx.doi.org/10.24959/sphhcj.18.114

17. Уніфікований клінічний протокол первинної, вторинної (спеціалізованої) та третинної (високоспеціалізованої) медичної допомоги дорослим. Туберкульоз [Електронний ресурс] : наказ МОЗ України від 04.09.2014 p. № 620. - Режим доступу : http://mtd.dec.gov.ua/images/dodatki/2014_620_ТВ/2014_620_ YKPMD_TB.pdf

18. ВО3. [Електронний ресурс] - Режим доступу : https://www.who.int/ru

19. Статистика: теоретичні засади і прикладні аспекти [Текст] : навч. посіб. / Р. В. Фещур, А. Ф. Барвінський, В. П. Кічор ; Нац. ун-т «Львівська політехніка», Ін-т післядиплом. освіти. - Вид. 2-ге, оновл. і доп. - Львів : Інтелект-Захід, 2003. - 576 с.

20. Про внесення змін до наказу Міністерства охорони здоров’я України від 28 вересня 2012 року № 751: наказ MO3 України від 29.12.1016 p. № 1422 [Електронний ресурс]. - Режим доступу : https:// zakon.rada.gov.ua/laws/show/z0530-17

21. Про протидію захворюванню на туберкульоз: Закон України № 2586 від 28.12.2015 р. [Електронний pecypc]. - Режим доступу : https://zakon.rada.gov.ua/laws/show/2586-14

\section{REFERENCES}

1. Zakon Ukrainy № 1287 vid 18.11.2003 r. (2003). Pro ratyfikatsiiu Uhody pro pozyku (Proekt «Kontrol za tuberkulozom ta VIL/SNIDom v Ukraini») mizh Ukrainoiu ta Mizhnarodnym bankom rekonstruktsii ta rozvytku. Available at: https://zakon.rada.gov.ua/laws/show/1287-15

2. Zakon Ukrainy № 2586 vid 28.12.2015 r. (2015). Pro protydiiu zakhvoriuvanniu na tuberkuloz. Available at: https://zakon.rada.gov.ua/laws/show/2586-1 
3. WHO releases the new International Classification of Diseases (ICD 11). (n.d.). World Health Organization (en-US).

4. Health systems expanding in the context of Health 2020: challenges and priorities in the WHO European Region (2015). Division of Health Systems and Public Health, World Health Organization, 3-4.

5. Rozporiadzhennia Kabinetu Ministriv Ukrainy vid 30.11.2016 № 1013-r. (2016). Pro skhvalennia Kontseptsii reformy finansuvannia systemy okhorony zdorovia. Available at: http://zakon3.rada.gov.ua/laws/show/10132016-\%D1\%80.

6. Kabachna, A. V., Shelkova, E. V., Kabachnyi, O. G. (2015). Indeks utylitarnosti yak indykator otsinky dotsilnosti vnesennia likarskykh zasobiv do lokalnoho formuliara. Menedzhment ta marketynh u skladi suchasnoi ekonomiky, nauky i osvity, praktyky: III nauk.-prakt. Internet-konf. Kharkiv, 118-120.

7. Yakovlieva, L. V., Herasymova, O. O., Horbachova, A. S., Krasiuk, A. A. (2015). Kliniko-ekonomichni aspekty farmakoterapii khvorykh na vyrazkovu khvorobu shlunka. Farmatsevtychnyi chasopys, 3, 83-87. https://doi.org/10.11603/2312-0967.2015.3.4939

8. Kotvitska, A. A., Krasulia, O. I., Kubarieva, I. V. (2012). Naukovo-praktychni pidkhody do stvorennia lokalnoho formuliaru likarskykh zasobiv u likuvalno-profilaktychnykh zakladakh statsionarnoho typu. Management, economy and quality assurance in pharmacy, 6, 70-75.

9. Kotvitska, A. A., Kononenko, O. V. (2015). Otsinka farmakoterapii khvorykh na kir v umovakh statsionaru metodamy ABC-, VEN- ta chastotnoho analizu. Farmatsevtychnyi zhurnal, 6, 3-9.

10. Mnushko, Z. M., Sholoiko, N. V. (2008). Farmakoeoknomichni pidkhody do stvorennia optymalnoho pereliku likarskykh preparativ, neobkhidnykh dlia zakupivli za biudzhetni koshty (na prykladi hematolohichnoho viddilennia klinichnoi likarni): metod. rek. Kharkiv: NFaU, 19.

11. Panfilova, H. L., Tsurikova, O. V. (2014). Rezultaty doslidzhennia tendernykh zakupivel likarskykh zasobiv dlia onkohematolohichnykh khvorykh v Ukraini. Zaporizkyi medychnyi zhurnal, 1(82), 98-103.

12. Panfilova, G., Tsurikova, O., Dorovskyy, O., \& Korzh, Y. (2015). The results of clinical and economic analysis of drug consumption in patients with acute lymphoid and myeloid leukemia in Ukraine. Clinical Pharmacy, 19(4), 17-23. http://dx.doi.org/10.24959/cphj.15.1361

13. Nemchenko, A. S., Nazarkina, V. N., \& Kurylenko, Y. Y. (2018). The study of the state of pharmaceutical provision for patients with cardiovascular diseases using ABC-and VEN-analyses. News of Pharmacy, 3(95), 44-48. https://doi.org/10.24959/nphj.18.2218

14. Nemchenko, A. S. Kosiachenko, K. L., Panfilova, H. L. (2011). Metodyka provedennia kliniko-ekonomichnoho analizu tendernykh zakupivel LZ za derzhavnymy tsilovymy prohramamy: metodychni rekomendatsii. Kharkiv: NFAU, 26.

15. Sadova, D. T., Hrom, O. L. (2010). Optymizatsiia metodyky rozrakhunku potreby v protytuberkuloznykh preparatakh na osnovi analizu kart istorii khvoroby. Farmatsevtychnyi zhurnal, 4, 27-31.

16. Fedyak, I., Kupnovytska, I., \& Hrynyk, N. (2018). Clinical and economic evaluation of pharmacotherapy of patients with tuberculosis in intensive therapy departments of antituberculosis dispensaries. Social Pharmacy In Health Care, 4(2), 19-28. http://dx.doi.org/10.24959/sphhcj.18.114

17. Nakaz MOZ Ukrainy vid 04.09.2014 r. № 620. (2014). Unifikovanyi klinichnyi protokol pervynnoi, vtorynnoi (spetsializovanoi) ta tretynnoi (vysokospetsializovanoi) medychnoi dopomohy doroslym. Tuberkuloz. Available at: http://mtd.dec.gov.ua/images/dodatki/2014_620_TB/2014_620_YKPMD_TB.pdf

18. WHO. (n.d.). Available at: https://www.who.int/en

19. Feshchur, R. V., Barvinskyi, A. F., Kichor, V. P. (2003). Statystyka: teoretychni zasady i prykladni aspekty: navch. posib. Nats. un-t «Lvivska politekhnika», In-t piliadyplom. osvity. Lviv : Intelekt-Zakhid, 576.

20. Nakaz MOZ Ukrainy vid 29.12.2016 № 1422. (2016). Pro vnesennia zmin do nakazu Ministerstva okhorony zdorov’ia Ukrainy vid 28 veresnia 2012 roku № 755. Available at: https://zakon.rada.gov.ua/laws/ show/z0530-17

21. Zakon Ukrainy № 2586 vid 28.12.2015 r. (2015). Pro protydiiu zakhvoriuvanniu na tuberkuloz. Available at: https://zakon.rada.gov.ua/laws/show/2586-14

Адреса для листування:

Надійшла до редакції 13.03 .2020 p.

61168, м. Харків, вул. Валентинівська, 4.

E-mail: romankot976@gmail.com.

Національний фармацевтичний університет

Romanko T. A. (ORCID - https://orcid.org/0000-0002-2440-6166)

Korzh I. V. (ORCID - https://orcid.org/0000-0002-0828-9772)

Proskurova Ya. O. (ORCID - https://orcid.org/0000-0001-9429-0149) 